\title{
Characterization and Monitoring of Drought during Pre and Post Industrialization Era of summer and Winter Monsoon by Using Non Parametric Test at South Gujarat, India
}

\author{
Neeraj Kumar, S.K. Chandrawanshi*, C.C. Panchal and G.G. Radadia \\ Agricultural Meteorological Cell, Department of Agriculutral Engineering, N. M. College of \\ Agriculture, Navsari Agricultural University, Navsari- 396 450, Gujarat, India \\ *Corresponding author
}

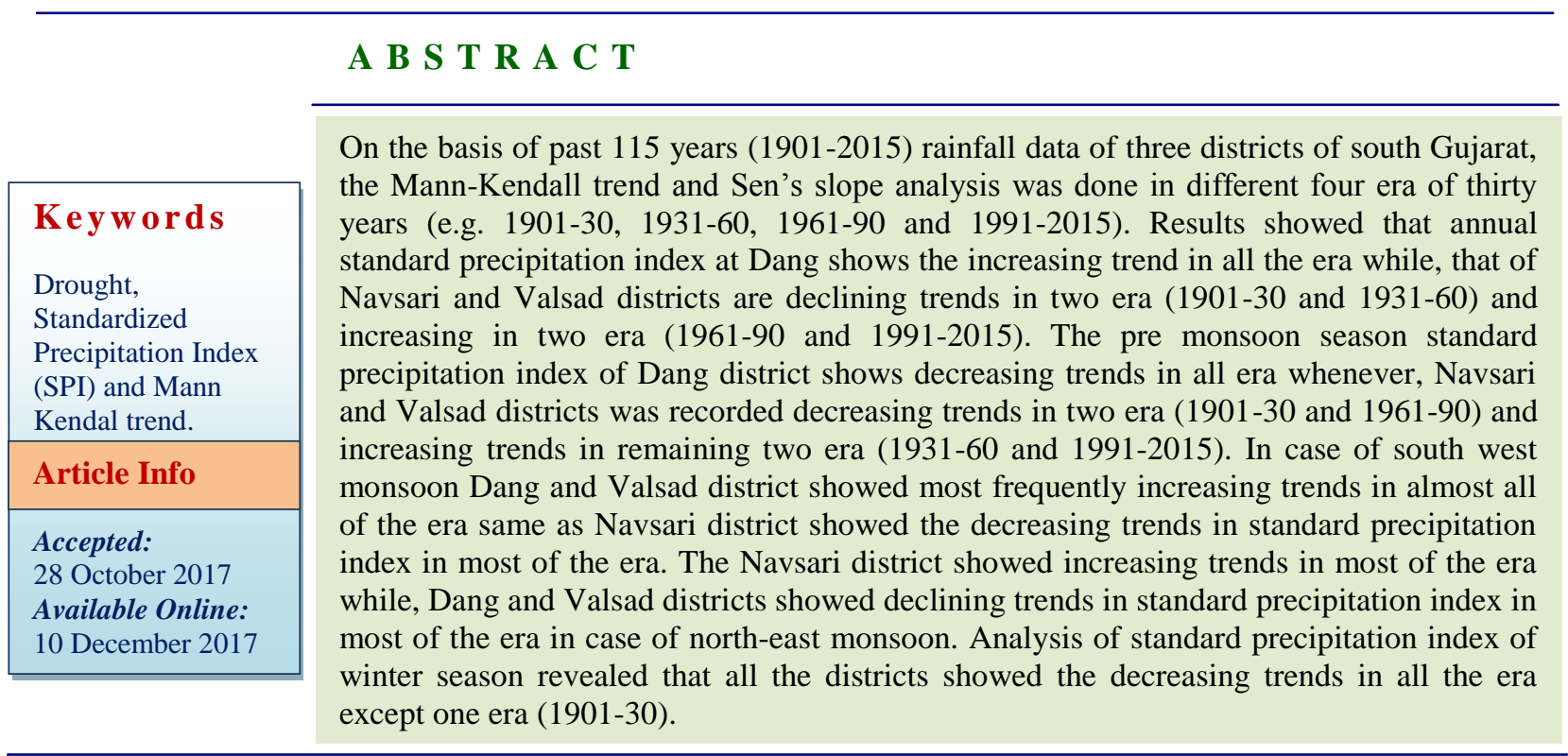

\section{Introduction}

Drought is an insidious natural hazard that results from lower levels of precipitations than what is considered normal. When this phenomenon extends over a season or a longer period of time, precipitation is insufficient to meet the demands of human activities and the environment. Drought must be considered a relative, rather than absolute, condition. There are also many different methodologies for monitoring drought. Droughts are regional in extent and each region has specific climatic characteristics.
Temperature, wind and relative humidity are also important factors to include in characterizing drought. Drought monitoring also needs to be application-specific because drought impacts will vary between sectors. Drought means different things to different users such as water managers, agricultural producers, hydroelectric power plant operators and wildlife biologists. Even within sectors, there are many different perspectives of drought because impacts may differ markedly. 
Droughts are commonly classified by type as meteorological, agricultural and hydrological, and differ from one another in intensity, duration and spatial coverage. Drought is a normal, recurrent feature of climate. It occurs almost everywhere, although its features vary from region to region. Defining drought is therefore difficult; it depends on differences in regions needs and disciplinary perspectives (Wilhite and Glantz, 1985). In the most general sense, drought originates from a deficiency of precipitation over an extended period of time, resulting in a water shortage for some activity, group, or environmental sector (Jain et al., 2009). Whatever the definition, it is clear that drought cannot be viewed solely as a physical phenomenon.

During drought, many people migrate to areas outside the drought affected area. One of the most severe noticeable effects of drought is famine. Drought is a serious meteorological hazard affecting the successful crop production. This assumes greater significance as more than 80 percent of the population in the state depends on agriculture and its allied sectors for livelihood. In order to sustain and enhance agricultural production against the weak monsoon, frequent dry spell condition and other extreme events, suitable mitigation and adaptation strategies need to be worked out and be taken up in the planning against drought. The variability of rainfall in both space and time affects the effective growing period. At a given location, soil type, available water holding capacity and evaporative demand determine the length of the growing season. The water availability to crops under rainfed condition was determined following agro-meteorological procedures in several regions (Ramana Rao et al., 1979; Gupta et al., 2010). Flexible time scale has been attributed as the fundamental strength of standardized precipitation index (SPI) to study drought over other indices (Mishra and Singh, 2010). South west summer monsoon, spreading from June to September is a grand period of rainfall in India as monsoonal torrents supply about $80 \%$ of India's annual rainfall (Chang, 1967; Bagla, 2006).

The dominant rainfall patterns for entire India were evolved through time series rainfall data from 1871-1990 analysis, using map-to-map correlation, fuzzy c-means clustering and empirical orthogonal functions (Kulkarni and Kriplani, 1998). It was observed that the rainfall from monsoons over entire India has no relation with its spatial distribution. Climate variability and climate change have been strongly associated with the water and energy cycle and associated extremes, such as drought. Global and regional land surface temperature have increased in the twentieth century and greater warming has been identified in the last three decades (WMO, 2012), with 11 of the 12 warmest years observed since 1850 occurring between 1995 and 2006 (Alley et al., 2007), with 11 of the 12 warmest years observed since 1850 occurring between 1995 and 2006. An analysis of the global mean surface air temperature and found that because of differential changes between daily maximum and minimum temperatures, the diurnal temperature range is narrowing. The effects have also been observed on the hydrologic cycle and its components as a result of changes in the climate variables, such as precipitation and air temperature.

The variability of rainfall in both space and time affects the effective growing period. At a given location, soil type, available water holding capacity and evaporative demand determine the length of the growing season (Sattar et al., 2013). The water availability to crops under rainfed condition was determined following agro-meteorological procedures in several regions (Gupta et al., 2010). Flexible time scale has been attributed as the fundamental strength of standardized 
precipitation index (SPI) to study drought over other indices (Mishra and Singh, 2010). Analyzing long term rainfall, determined the length of growing period for crop planning in Coimbatore district. Looking to every facet of the drought situation, moisture availability periods are required to be characterized for proper assessment of rainfall resource towards developing effective management strategy for its optimum utilization for crop production under rainfed condition.

\section{Materials and Methods}

In south Gujarat five locations were selected for assessment of rainfall intensity and frequency (1) Navsari $\left(23.15^{\circ} \mathrm{N}\right.$ and $69.49^{\circ} \mathrm{E}$, Altitude $11.0 \mathrm{~m})$ (2) Valsad $\left(22.35^{\circ} \mathrm{N}\right.$ and $72.35^{\circ} \mathrm{E}$, Altitude $6.10 \mathrm{~m}$ ) and (3) Dangs $\left(20.51^{\circ} \mathrm{N}\right.$ and $70.21^{\circ} \mathrm{E}$, Altitude $440 \mathrm{~m}$ ) (Fig. 1 and 2). The historical monthly and annual rainfall data were used of 115 years (19012015).

\section{Standardized Precipitation Index (SPI)}

The definition of drought proposed by Mckee et al., (1993) employing the Standard precipitation index (SPI) is used to measured drought for time scale ranging from $3,6,12$, 24 and 48 months. The gamma distribution has been found to fit climatological precipitation time series well therefore, computation of the SPI involves fitting a gamma probability density function given a series of monthly precipitation totals for station. The resulting parameters are then used to find the probability of a particular precipitation event over a given time scale. This probability is then converted to the standard normal random variable $\mathrm{Z}$, which is the SPI index value.

SPI approach SPI was developed in Colorado by McKee et al., (1993), is based on the probability distribution of precipitation and requires less input data and calculation efforts then PDSI, and is reported to be able to identify emerging droughts sooner than Palmer Index. The basis of SPI approach is the calculating probabilities of precipitation for each time scale. In a general point of view, for analyzing the precipitation data in monthly scale during a record period (preferably 30 years or more), it is required to form total precipitation time series in an ideal scale.

The main problem in this case is fitting an appropriate statistical distribution on a particular time series. (Edward and Mckee, 1997) realized that gamma distribution fits well for some climatological data such as precipitation time series. To obtain experimental accumulation probabilities, first precipitation data will be arranged as ascendant then the value of experimental probabilities. For an easy access to $\mathrm{Z}$ or SPI values, it is better to use (Edward and Mckee, 1997) this approximation transform the accumulation possibilities to standard normal random variant. Actually SPI is a standard variant that shows diversion values upper or lower than average. Different applications of SPI including:

(1) Drawing SPI series (in each time scale) in a chart is a good index of drought phenomenon in a particular place.

(2) SPI can be used for spatial analysis of drought, so makes it possible to compare different stations in various climatic regions ignoring differences between their normal precipitations.

(3) SPI can be calculated for short time scales (for example, one month) and

(4) By studying drought, it is possible to analyze frequency and duration of different values of SPI. 


\section{Calculation of SPI}

The SPI was developed by Mckee et al., (1993) to quantify precipitation anomaly with respect to long-term normal conditions for multiple time scales. SPI can be calculated at various time scales on which precipitation deficits/surpluses can affect different aspects of the hydrologic cycle, which is the main advantage of the SPI. This advantage is crucial because it can reflect the natural lags in the response of different water sources, such as river discharge and storage, to precipitation anomalies (Paulo et al., 2005). Also follow WMO, (2012), Standard precipitation index (SPI) guideline for calculating SPI.

In order to analysis the impact of rainfall deficiency on drought development in this terrain, SPI has been used to quantify the precipitation deficit in the monsoon and the non-monsoon periods since 1901 up to 2015 , table 1. The SPI is calculated using the following equation, written as

$\mathrm{SPI}=(\mathrm{Xij}-\mathrm{Xim}) / \sigma$

Where, $\mathrm{Xij}$ is the actual rainfall, $\mathrm{Xim}$ is normal rainfall and $\sigma$ is its standard deviation.

\section{Trend analysis}

\section{Mann-Kendall test}

The trend analysis and estimation of Sen's slope are done using Kendall (1975) and Sen (1968) method, respectively for the given data sets. Man-Kendall test is a non-parametric test for finding trends in time series. This test compares the relative magnitudes of data rather than data values themselves (Gilbert, 1987). The benefit of this test is that data need not to confirm any particular distribution. In this test, each data value in the time series is compared with all subsequent values. Initially the Mann-Kendall statistics $(S)$ is assumed to be zero, and if a data value in subsequent time periods is higher than a data value in previous time period, $S$ is incremented by 1 , and viceversa. The net result of all such increments and decrements gives the final value of $S$. The Mann-Kendall statistics $(S)$ is given as:

$S=\sum_{i=1}^{n-1} \sum_{j=i+1}^{n} \operatorname{sign}\left(x_{j}-x_{i}\right)$

Where, sign $\left(x_{j}-x_{k}\right)=1$, if $\left(x_{j}-x_{k}\right)>0$; 0 , if $\left(x_{j}^{-}\right.$ $\left.x_{k}\right)=0$; 1 if $\left(x_{j}-x_{k}\right)<0$.

A positive value of $S$ indicates an increasing trend, and a negative value indicates a decreasing trend. However, it is necessary to perform the statistical analysis for the significance of the trend. The test procedure using the normal approximation test is described by Kendall (1975). This test assumes that there are not many tied values within the dataset. The variance $(S)$ is calculated by the following equation:

$$
\begin{aligned}
& \text { Var } \\
& \frac{1}{18}\left[n(n-1)(2 n+5)-\sum_{p=1}^{g} t_{p}\left(t_{p}-1\right)\left(2 t_{p}+5\right)\right]
\end{aligned}=
$$

Where, $\mathrm{n}$ is the number of data points, $\mathrm{g}$ is the number of tied groups and $t_{p}$ is the number of data points in the $p^{\text {th }}$ group.

The normal Z-statistics is computed as:

$Z=\left\{\begin{array}{l}\frac{S-1}{\sqrt{\operatorname{Var}(S)},} \text { if } S>0 \\ 0 \quad \text { if } S=0 \\ \sqrt{\operatorname{Var}(S)}, \text { if } S>0\end{array}\right.$

The trend is said to be decreasing if $\mathrm{Z}$ is negative and the computed Z-statistics is greater than the z-value corresponding to the $5 \%$ level of significance. The trend is said to 
be increasing if the $\mathrm{Z}$ is positive and the computed Z- statistics is greater than the $\mathrm{z}$ value corresponding to the $5 \%$ level of significance. If the computed Z-statistics is less than the $\mathrm{z}$-value corresponding to the $5 \%$ level of significance, there is no trend.

\section{Sen's slope estimator}

Simple linear regression is one of the most widely used model to detect the linear trend. However, this method requires the assumption of normality of residuals (McBean and Motiee, 2008). Viessman et al., (1989) reported that many hydrological variables exhibit a marked right skewness partly due to the influence of natural phenomena and do not follow a normal distribution.

Thus the Sen (1968) slope estimator is found to be a powerful tool to develop the linear relationships. Sen's slope has the advantage over the regression slope in the sense that it is not much affected by gross data errors and outliers. The Sen's slope is estimated as the median of all pair-wise slopes between each pair of points in the dataset (Thiel, 1950; Sen, 1968; Helsel and Hirsch, 2002). Each individual slope $\left(m_{i j}\right)$ is estimated using the following equation:

$m_{i j}=\frac{\left(Y_{j}-Y_{i}\right)}{(j-1)}$

Where, $i=1$ to $n-1, j=2$ to $n, Y_{j}$ and $Y_{i}$ are data values at time $j$ and $i(j>i)$, respectively. If there are $n$ values of $Y_{j}$ in the time series, there will be $N=n(n-1) / 2$ slope estimates. The Sen's slope is the median slope of these $N$ values of slopes. The Sen's slope is:

$$
m=m_{\left[\frac{N+1}{2}\right]} \text { if } n \text { is odd }
$$

$m=\frac{1}{2}\left(m_{\left[\frac{N}{2}\right]}+m_{\left[\frac{N+2}{2}\right]}\right)$, if $n$ is even

Positive Sen's slope indicates rising trend while negative Sen's slope indicates falling trend.

\section{Results and Discussion}

\section{Pre industrialization era (1901-30)}

\section{Pre monsoon season}

Standard precipitation index of pre monsoon season at south Gujarat from years 1901-03 are presented in table 2. The decreasing rainfall trends were found at Navsari, Dang and Valsad with the rate of $-0.053,-0.029$ and $-0.160 \mathrm{~mm}$ per year. The analysis of MannKendall test shows decreasing trend with Sen's slope 0.000 at all the three districts.

\section{Dang district}

The data analysis of Dang district from table 2 showed that during pre-monsoon season of south Gujarat showed decreasing trend with Kendall's tau value -0.029 and S- Statistics 10.000 with the Sen's Slope value of 0.000 .

\section{Navsari district}

At Navsari district the pre monsoon season, analysis of SPI trends showed the decreasing trends in case of year 1901-30 with the lower value of Kendall's tau of - 0.053, S- Statistics of -21.000 and Sen's Slope of 0.000 (Table 2).

\section{Valsad district}

In case of Valsad the SPI trend of pre monsoon season observed decreasing trends. Analysis also revealed that there is a lower values of Kendall's tau (-0.074), S- Statistics (-31.000) and Sen's Slope (0.000) (Table 2). 


\section{South west monsoon season}

Standard precipitation index of south west monsoon season at south Gujarat from years 1901-03 are presented in table 2. The significant decreasing trend was noticed at Navsari district with the annual rate of rate of $-0.076 \mathrm{~mm}$. The increasing SPI trends were found at Dang and Valsad with the rate of 0.148 and $0.085 \mathrm{~mm}$ per year. The analysis of Mann-Kendall test shows increasing trend with Sen's slope at all the districts except Navsari district.

\section{Dang district}

The data analysis of Dang district from table 2 showed that during south west monsoon season of south Gujarat showed increasing trend with Kendall's tau value 0.148 and SStatistics 56.000 with the Sen's Slope value of 0.019 .

\section{Navsari district}

At Navsari district the south west monsoon season, analysis of SPI trends showed the decreasing trends in case of year 1901-30 with the lower value of Kendall's tau of 0.076 , S- Statistics of -33.000 and Sen's Slope of 0.016 (Table 2).

\section{Valsad district}

In case of Valsad the SPI trend of pre monsoon season observed increasing trends. Analysis also revealed that there is a lower value of Kendall's tau (0.085), S- Statistics (37.000) and Sen's Slope (0.020) (Table 2).

\section{North east monsoon}

Standard precipitation index of north east monsoon season at south Gujarat from years 1901-03 are presented in table 2. The significant decreasing trend was noticed at
Dang and Valsad district with the annual rate of rate of $-0.056 \mathrm{~mm}$ and $-0.012 \mathrm{~mm}$. The increasing SPI trends were found at Navsari with the rate of $0.037 \mathrm{~mm}$ per year. The analysis of Mann-Kendall test shows increasing trend with Sen's slope at these districts.

\section{Dang district}

The data analysis of Dang district from table 2 showed that during north east monsoon season of south Gujarat showed decreasing trend with Kendall's tau value -0.056 and SStatistics -21.000 with the Sen's Slope value of -0.002 .

\section{Navsari district}

At Navsari district the north east monsoon season, analysis of SPI trends showed the increasing trends in case of year 1901-30 with the lower value of Kendall's tau of 0.037 , SStatistics of 16.000 and Sen's Slope of 0.000 (Table 2).

\section{Valsad district}

In case of Valsad the SPI trend of pre monsoon season observed decreasing trends. Analysis also revealed that there is a lower value of Kendall's tau (-0.012), S- Statistics ($5.000)$ and Sen's Slope (0.000) (Table 2).

\section{Winter season}

Standard precipitation index of winter season at south Gujarat from years 1901-03 are presented in table 2. The significant decreasing trend was noticed at Valsad district with the annual rate of rate of -0.009 $\mathrm{mm}$. The increasing SPI trends were found at Dang and Navsari with the rate of 0.050 and $0.077 \mathrm{~mm}$ per year. The analysis of MannKendall test shows increasing trend with Sen's slope at these districts. 


\section{Dang district}

The data analysis of Dang district from table 2 showed that during winter season showed increasing trend with Kendall's tau value 0.050 and S- Statistics 18.000 with the Sen's Slope value of 0.000 .

\section{Navsari district}

At Navsari district the winter season, analysis of SPI trends showed the increasing trends in case of year 1901-30 with the lower value of Kendall's tau of 0.077 , S- Statistics of 33.000 and Sen's Slope of 0.003 (Table 2).

\section{Valsad district}

In case of Valsad the SPI trend of winter season observed decreasing trends. Analysis also revealed that there is a lower value of Kendall's tau (-0.009), S- Statistics (-4.000) and Sen's Slope (0.000) (Table 2).

\section{Annual}

Standard precipitation index of annual rainfall at south Gujarat from years 1901-03 are presented in table 2 . The significant increasing trend was noticed at Dang and Valsad district with the annual rate of rate of $0.132 \mathrm{~mm}$ and $0.090 \mathrm{~mm}$. The decreasing SPI trends were found at Navsari with the rate of $0.076 \mathrm{~mm}$ per year (Table 2).

\section{Dang district}

The data analysis of Dang district from table 2 showed that during annual season showed increasing trend with Kendall's tau value 0.132 and S- Statistics 50.000 with the Sen's Slope value of 0.014 .

\section{Navsari district}

At Navsari district the annual season, analysis of SPI trends showed the decreasing trends in case of year 1901-30 with the lower value of Kendall's tau of -0.076, S- Statistics of 33.000 and Sen's Slope of -0.013 (Table 2).

\section{Valsad district}

In case of Valsad the SPI trend of annual season observed increasing trends.

Analysis also revealed that there is a lower value of Kendall's tau (0.090), S- Statistics (39.000) and Sen's Slope (0.021) (Table 2).

\section{Pre industrialization era (1931-60)}

\section{Pre monsoon season}

Standard precipitation index of pre monsoon season at south Gujarat from years 1931-60 are presented in table 3 .

The significant increasing trend was noticed at the entire district.

\section{Dang district}

The data analysis of Dang district from table 3 showed that during pre-monsoon season of south Gujarat showed increasing trend with Kendall's tau value 0.084 and S- Statistics 97.000 with the Sen's Slope value of 0.019.

\section{Navsari district}

At Navsari district the pre monsoon season, analysis of SPI trends showed the increasing trends in case of year 1931-60 with the lower value of Kendall's tau of 0.111 , S- Statistics of 43.000 and Sen's Slope of 0.000 (Table 3).

\section{Valsad district}

In case of Valsad the SPI trend of pre monsoon season observed increaing trends. Analysis also revealed that there is a lower value of Kendall's tau (0.131), S- Statistics (53.000) and Sen's Slope (0.000) (Table 3). 


\section{South west monsoon season}

Standard precipitation index of south west monsoon season at south Gujarat from years 1931-60 are presented in table 3. The significant decreasing trend was noticed at Dang district with the annual rate of rate of $9.000 \mathrm{~mm}$. The increasing SPI trends were found at Navsari and Valsad with the rate of 0.094 and $0.136 \mathrm{~mm}$ per year.

The analysis of Mann-Kendall test shows increasing trend with Sen's slope at all the districts except Dang district.

\section{Dang district}

The data analysis of Dang district from table 2 showed that during south west monsoon season of south Gujarat showed decreasing trend with Kendall's tau value -9.000 and SStatistics 0.877 with the Sen's Slope value of -0.006 .

\section{Navsari district}

At Navsari district the south west monsoon season, analysis of SPI trends showed the increasing trends in case of year 1931-60 with the higher value of Kendall's tau of 0.094, SStatistics of -41.000 and Sen's Slope of 0.020 (Table 3).

\section{Valsad district}

In case of Valsad the SPI trend of pre monsoon season observed increasing trends. Analysis also revealed that there is a lower value of Kendall's tau (0.136), S- Statistics (59.000) and Sen's Slope (0.027) (Table 3).

\section{North east monsoon}

Standard precipitation index of north east monsoon season at south Gujarat from years 1931-60 are presented in table 3. The significant decreasing trend was noticed at all the districts because of lower values of Kendall's tau, S- Statistics and Sen's Slope.

\section{Dang district}

The data analysis of Dang district from table 3 showed that during north east monsoon season of south Gujarat showed decreasing trend with Kendall's tau value -48.000 and SStatistics 0.402 with the Sen's Slope value of -0.007 .

\section{Navsari district}

At Navsari district the north east monsoon season, analysis of SPI trends showed the decreasing trends in case of year 1931-60 with the lower value of Kendall's tau of 0.090, S- Statistics of -39.000 and Sen's Slope of -0.007 (Table 3).

\section{Valsad district}

In case of Valsad the SPI trend of north east monsoon season observed decreasing trends. Analysis also revealed that there is a lower value of Kendall's tau (-0.044), S- Statistics (19.000) and Sen's Slope (-0.001) (Table 3).

\section{Winter season}

Standard precipitation index of winter season at south Gujarat from years 1931-60 are presented in table 3. The significant decreasing trend was noticed at the entire district because of lower value of Kendall's tau, S- Statistics and Sen's Slope.

\section{Dang district}

The data analysis of Dang district from table 3 showed that during winter season showed decreasing trend with Kendall's tau value 109.000 and S- Statistics 0.044 with the Sen's Slope value of- 0.012 . 


\section{Navsari district}

At Navsari district the winter season, analysis of SPI trends showed the decreasing trends in case of year 1931-60 with the lower value of Kendall's tau of -0.170, S- Statistics of 63.000 and Sen's Slope of 0.000 (Table 3).

\section{Valsad district}

In case of Valsad the SPI trend of winter season observed decreasing trends. Analysis also revealed that there is a lower value of Kendall's tau (-0.232), S- Statistics (-94.000) and Sen's Slope (-0.012) (Table 3).

\section{Annual}

Standard precipitation index of annual rainfall at south Gujarat from years 1931-60 are presented in table 3 .

The significant increasing trend was noticed at all the district of south Gujarat.

\section{Dang district}

The data analysis of Dang district from table 3 showed that during annual season showed increasing trend with Kendall's tau value 7.000 and S- Statistics 0.915 with the Sen's Slope value of 0.002 .

\section{Navsari district}

At Navsari district the annual season, analysis of SPI trends showed the increasing trends in case of year 1931-60 with the lower value of Kendall's tau of 0.136, S- Statistics of 59.000 and Sen's Slope of 0.021 (Table 3).

\section{Valsad district}

In case of Valsad the SPI trend of annual season observed increasing trends. Analysis also revealed that there is a lower value of
Kendall's tau (0.126), S- Statistics (55.000) and Sen's Slope (0.022) (Table 3).

\section{Pre industrialization era (1961-90)}

\section{Pre monsoon season}

Standard precipitation index of pre monsoon season at south Gujarat from years 1961-90 are presented in table 4 .

The significant decreasing trend was noticed at the entire districts of south Gujarat.

\section{Dang district}

The data analysis of Dang district from table 3 showed that during pre-monsoon season of south Gujarat showed decreasing trend with Kendall's tau value - 0.243 and S- Statistics 92.000 with the Sen's Slope value of 0.000 .

\section{Navsari district}

At Navsari district the pre monsoon season, analysis of SPI trends showed the decreasing trends in case of year 1961-90 with the lower value of Kendall's tau of -0.012, S- Statistics of -4.000 and Sen's Slope of 0.000 (Table 4).

\section{Valsad district}

In case of Valsad the SPI trend of pre monsoon season observed decreasing trends.

Analysis also revealed that there is a lower value of Kendall's tau (-0.129), S- Statistics (42.000) and Sen's Slope (0.000) (Table 4).

\section{South west monsoon season}

Standard precipitation index of south west monsoon season at south Gujarat from years 1961-90 are presented in table 3. The significant decreasing trend was noticed at Navsari and Valsad district with the annual 
rate of rate of -0.297 and $-0.07 \mathrm{~mm}$. The increasing SPI trends were found at Dang with the rate of $0.021 \mathrm{~mm}$ per year.

\section{Dang district}

The data analysis of Dang district from table 2 showed that during south west monsoon season of south Gujarat showed increasing trend with Kendall's tau value 0.021 and SStatistics 9.000 with the Sen's Slope value of 0.002 .

\section{Navsari district}

At Navsari district the south west monsoon season, analysis of SPI trends showed the decreasing trends in case of year 1961-90 with the lower value of Kendall's tau of -
0.297, S- Statistics of -129.000 and Sen's Slope of -0.047 (Table 4).

\section{Valsad district}

In case of Valsad the SPI trend of pre monsoon season observed decreasing trends. Analysis also revealed that there is a lower value of Kendall's tau (-0.007), S- Statistics (3.000) and Sen's Slope (-0.002) (Table 4).

\section{North east monsoon}

Standard precipitation index of north east monsoon season at south Gujarat from years 1961-90 are presented in table 4. The significant increasing trend was noticed at all the districts because of lower values of Kendall's tau, S- Statistics and Sen's Slope.

Fig.1 and 2 Location map
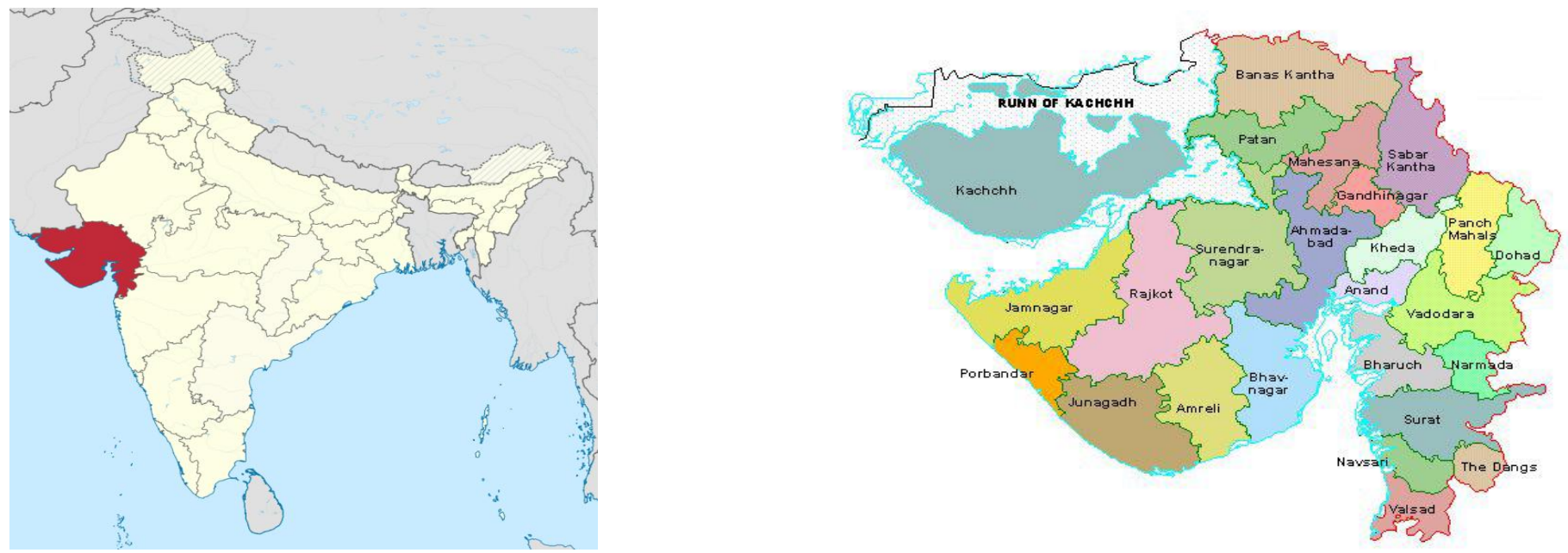

Table.1 Dryness/wetness categories according to SPI values (source: McKee et al., 1993)

\begin{tabular}{ccc}
\hline Class & Symbol & SPI \\
\hline Extremely wet & EW & $>2$ \\
Severely wet & SW & 1.5 to 1.99 \\
Moderately wet & Mw & 1 to 1.49 \\
Near Normal & NN & -0.99 to 0.99 \\
Moderately dry & MD & -1 to -1.49 \\
Very dry & VD & -1.5 to -1.99 \\
Extremely dry & ED & $<-2$ \\
\hline
\end{tabular}


Table.2 Mann-Kendall trend analysis of Standard precipitation index (SPI) at Dang, Navsari and Valsad from 1901 to 1930

\begin{tabular}{|c|c|c|c|c|c|c|}
\hline Station & Season & Kendall's tau & S- Statistics & P Value & Sen's Slope & Trend \\
\hline \multirow{5}{*}{ Dang } & Pre monsoon & -0.029 & -10.000 & 0.853 & 0.000 & Rising \\
\hline & South-west monsoon & 0.148 & 56.000 & 0.277 & 0.019 & Falling \\
\hline & North-east monsoon & -0.056 & -21.000 & 0.693 & -0.002 & Falling \\
\hline & Winter & 0.050 & 18.000 & 0.732 & 0.000 & Falling \\
\hline & Annual & 0.132 & 50.000 & 0.333 & 0.014 & Rising \\
\hline \multirow{5}{*}{ Navsari } & Pre monsoon & -0.053 & -21.000 & 0.712 & 0.000 & Rising \\
\hline & South-west monsoon & -0.076 & -33.000 & 0.568 & -0.016 & Rising \\
\hline & North-east monsoon & 0.037 & 16.000 & 0.788 & 0.000 & Falling \\
\hline & Winter & 0.077 & 33.000 & 0.566 & 0.003 & Rising \\
\hline & Annual & -0.076 & -33.000 & 0.568 & -0.013 & Rising \\
\hline \multirow{5}{*}{ Valsad } & Pre monsoon & -0.074 & -31.000 & 0.588 & 0.000 & Rising \\
\hline & South-west monsoon & 0.085 & 37.000 & 0.521 & 0.020 & Rising \\
\hline & North-east monsoon & -0.012 & -5.000 & 0.943 & 0.000 & Falling \\
\hline & Winter & -0.009 & -4.000 & 0.957 & 0.000 & Falling \\
\hline & Annual & 0.090 & 39.000 & 0.498 & 0.021 & Rising \\
\hline
\end{tabular}

Table.3 Mann-Kendall trend analysis of Standard precipitation index (SPI) at Dang, Navsari and Valsad from 1931 to 1960

\begin{tabular}{|c|c|c|c|c|c|c|}
\hline Station & Season & Kendall's tau & S- Statistics & P Value & Sen's Slope & Trend \\
\hline \multirow{5}{*}{ Dang } & Pre monsoon & 0.084 & 97.000 & -0.021 & 0.019 & Rising \\
\hline & South-west monsoon & -9.000 & 0.887 & -0.110 & -0.006 & Rising \\
\hline & North-east monsoon & -48.000 & 0.402 & -0.277 & -0.007 & Falling \\
\hline & Winter & -109.000 & 0.044 & 0.016 & -0.012 & Rising \\
\hline & Annual & 7.000 & 0.915 & 0.915 & 0.002 & Rising \\
\hline \multirow{5}{*}{ Navsari } & Pre monsoon & 0.111 & 43.000 & 0.428 & 0.000 & Falling \\
\hline & South-west monsoon & 0.094 & 41.000 & 0.475 & 0.020 & Falling \\
\hline & North-east monsoon & -0.090 & -39.000 & 0.498 & -0.007 & Falling \\
\hline & Winter & -0.170 & -63.000 & 0.228 & 0.000 & Falling \\
\hline & Annual & 0.136 & 59.000 & 0.301 & 0.021 & Falling \\
\hline \multirow{5}{*}{ Valsad } & Pre monsoon & 0.131 & 53.000 & 0.340 & 0.000 & Falling \\
\hline & South-west monsoon & 0.136 & 59.000 & 0.301 & 0.027 & Rising \\
\hline & North-east monsoon & -0.044 & -19.000 & 0.748 & -0.001 & Rising \\
\hline & Winter & -0.232 & -94.000 & 0.088 & -0.012 & Falling \\
\hline & Annual & 0.126 & 55.000 & 0.335 & 0.022 & Falling \\
\hline
\end{tabular}


Table.4 Mann-Kendall trend analysis of Standard precipitation index (SPI) at Dang, Navsari and Valsad from 1961 to 1990

\begin{tabular}{|c|c|c|c|c|c|c|}
\hline Station & Season & Kendall's tau & S- Statistics & P Value & Sen's Slope & Trend \\
\hline \multirow{5}{*}{ Dang } & Pre monsoon & -0.243 & -92.000 & 0.082 & 0.000 & Rising \\
\hline & South-west monsoon & 0.021 & 9.000 & 0.887 & 0.002 & Falling \\
\hline & North-east monsoon & 0.145 & 63.000 & 0.269 & 0.017 & Falling \\
\hline & Winter & -0.136 & -46.000 & 0.351 & 0.000 & Falling \\
\hline & Annual & 0.016 & 7.000 & 0.915 & 0.004 & Rising \\
\hline \multirow{5}{*}{ Navsari } & Pre monsoon & -0.012 & -4.000 & 0.950 & 0.000 & Rising \\
\hline & South-west monsoon & -0.297 & -129.000 & 0.022 & -0.047 & Rising \\
\hline & North-east monsoon & 0.094 & 40.000 & 0.485 & 0.006 & Falling \\
\hline & Winter & -0.015 & -5.000 & 0.932 & 0.000 & Rising \\
\hline & Annual & -0.283 & -123.000 & 0.030 & -0.047 & Rising \\
\hline \multirow{5}{*}{ Valsad } & Pre monsoon & -0.129 & -42.000 & 0.381 & 0.000 & Rising \\
\hline & South-west monsoon & -0.007 & -3.000 & 0.972 & -0.002 & Rising \\
\hline & North-east monsoon & 0.253 & 108.000 & 0.055 & 0.030 & Falling \\
\hline & Winter & 0.564 & 194.000 & $<0.0001$ & 0.019 & Falling \\
\hline & Annual & -0.002 & -1.000 & 1.000 & 0.000 & Rising \\
\hline
\end{tabular}

Table.5 Mann-Kendall trend analysis of Standard precipitation index (SPI) at Dang, Navsari and Valsad from 1991 to 2015

\begin{tabular}{|c|c|c|c|c|c|c|}
\hline Station & Season & Kendall's tau & S- Statistics & P Value & Sen's Slope & Trend \\
\hline \multirow{5}{*}{ Dang } & Pre monsoon & -0.035 & -5.000 & 0.868 & 0.000 & Rising \\
\hline & South-west monsoon & 0.067 & 20.000 & 0.657 & 0.005 & Falling \\
\hline & North-east monsoon & -0.360 & -108.000 & 0.012 & -0.049 & Falling \\
\hline & Winter & -0.189 & -16.000 & 0.298 & 0.000 & Falling \\
\hline & Annual & 0.007 & 2.000 & 0.981 & 0.001 & Rising \\
\hline \multirow{5}{*}{ Navsari } & Pre monsoon & 0.087 & 21.000 & 0.596 & 0.000 & Rising \\
\hline & South-west monsoon & 0.147 & 44.000 & 0.315 & 0.026 & Rising \\
\hline & North-east monsoon & 0.017 & 5.000 & 0.925 & 0.000 & Falling \\
\hline & Winter & -0.188 & -47.000 & 0.235 & 0.000 & Rising \\
\hline & Annual & 0.127 & 38.000 & 0.388 & 0.023 & Rising \\
\hline \multirow{5}{*}{ Valsad } & Pre monsoon & 0.018 & 5.000 & 0.924 & 0.000 & Rising \\
\hline & South-west monsoon & 0.007 & 2.000 & 0.981 & 0.002 & Rising \\
\hline & North-east monsoon & -0.084 & -25.000 & 0.574 & -0.001 & Falling \\
\hline & Winter & -0.407 & -104.000 & 0.009 & -0.013 & Falling \\
\hline & Annual & -0.033 & -10.000 & 0.834 & -0.006 & Rising \\
\hline
\end{tabular}




\section{Dang district}

The data analysis of Dang district from table 4 showed that during north east monsoon season of south Gujarat showed increasing trend with Kendall's tau value 0.145 and SStatistics 63.000 with the Sen's Slope value of 0.017 .

\section{Navsari district}

At Navsari district the north east monsoon season, analysis of SPI trends showed the increasing trends in case of year 1961-90.

With the lower value of Kendall's tau of 0.094, S- Statistics of 40.000 and Sen's Slope of 0.006 (Table 4).

\section{Valsad district}

In case of Valsad the SPI trend of north east monsoon season observed increasing trends.

Analysis also revealed that there is a lower value of Kendall's tau (0.253), S- Statistics (108.000) and Sen's Slope (0.030) (Table 4).

\section{Winter season}

Standard precipitation index of winter season at south Gujarat from years 1961-90 are presented in table 4 .

The significant decreasing trend was noticed at the entire district except Valsad district because of lower value of Kendall's tau, SStatistics and Sen's Slope.

\section{Dang district}

The data analysis of Dang district from table 4 showed that during winter season showed decreasing trend with Kendall's tau value 0.136 and S- Statistics -46.000 with the Sen's Slope value of 0.000 .

\section{Navsari district}

At Navsari district the winter season, analysis of SPI trends showed the decreasing trends in case of year 1961-90 with the lower value of Kendall's tau of -0.015 , S- Statistics of -5.000 and Sen's Slope of 0.000 (Table 4).

\section{Valsad district}

In case of Valsad the SPI trend of winter season observed increasing trends.

Analysis also revealed that there is a lower value of Kendall's tau (0.564), S- Statistics (194.000) and Sen's Slope (0.019) (Table 4).

\section{Annual}

Standard precipitation index of annual rainfall at south Gujarat from years 1961-90 are presented in table 4 .

The significant increasing trend was noticed at Dang district of south Gujarat at the rate of $0.016 \mathrm{~mm}$ per year.

In case of Navsari and Valsad showed decreasing trends of SPI with the lower value of Kendall's tau.

\section{Dang district}

The data analysis of Dang district from table 4 showed that during annual season showed increasing trend with Kendall's tau value 0.016 and S- Statistics 7.000 with the Sen's Slope value of 0.004 .

\section{Navsari district}

The data analysis of Dang district from table 4 showed that during annual season showed decreasing trend with Kendall's tau value 0.283 and S- Statistics -123.000 with the Sen's Slope value of -0.047 . 


\section{Valsad district}

In case of Valsad the SPI trend of annual season observed decreasing trends. Analysis also revealed that there is a lower value of Kendall's tau (-0.002), S- Statistics (-1.000) and Sen's Slope (0.000) (Table 4).

\section{Pre industrialization era (1991-2015)}

\section{Pre monsoon season}

Standard precipitation index of pre monsoon season at south Gujarat from years 1991-2015 are presented in table 5.

The significant increasing trend was noticed at the Navsari and Valsad of south Gujarat with the rate of 0.087 and $0.018 \mathrm{~mm}$ per year, in case of Dang district showed decreasing trend.

\section{Dang district}

The data analysis of Dang district from table 5 showed that during pre-monsoon season of south Gujarat showed decreasing trend with Kendall's tau value -0.035 and S- Statistics 5.000 with the Sen's Slope value of 0.000 .

\section{Navsari district}

At Navsari district the pre monsoon season, analysis of SPI trends showed the increasing trends in case of year 1991-2015 with the lower value of Kendall's tau of 0.087 , SStatistics of 21.000 and Sen's Slope of 0.000 (Table 5).

\section{Valsad district}

In case of Valsad the SPI trend of pre monsoon season observed increasing trends. Analysis also revealed that there is a lower value of Kendall's tau (0.018), S- Statistics (5.000) and Sen's Slope (0.000) (Table 5).

\section{South west monsoon season}

Standard precipitation index of south west monsoon season at south Gujarat from years 1991-2015 are presented in table 5.

The significant increasing trend was noticed at all the district of south Gujarat.

\section{Dang district}

The data analysis of Dang district from table 5 showed that during south west monsoon season of south Gujarat showed increasing trend with Kendall's tau value 0.067 and SStatistics 20.000 with the Sen's Slope value of 0.005 .

\section{Navsari district}

At Navsari district the south west monsoon season, analysis of SPI trends showed the increasing trends in case of year 1961-90 with the lower value of Kendall's tau of 0.147 , SStatistics of 44.000 and Sen's Slope of 0.026 (Table 5).

\section{Valsad district}

In case of Valsad the SPI trend of south west monsoon season observed increasing trends.

Analysis also revealed that there is a lower value of Kendall's tau (0.007), S- Statistics (2.000) and Sen's Slope (0.002) (Table 5).

\section{North east monsoon}

Standard precipitation index of north east monsoon season at south Gujarat from years 1991-2015 are presented in table 5.

The significant decreasing trend was noticed at all the districts except Navsari district because of lower values of Kendall's tau, SStatistics and Sen's Slope. 


\section{Dang district}

The data analysis of Dang district from table 5 showed that during north east monsoon season of south Gujarat showed decreasing trend with Kendall's tau value -0.360 and $S$ Statistics -108.000 with the Sen's Slope value of -0.049 .

\section{Navsari district}

At Navsari district the north east monsoon season, analysis of SPI trends showed the increasing trends in case of year 1991-2015 with the lower value of Kendall's tau of 0.017, S- Statistics of 5.000 and Sen's Slope of 0.000 (Table 5).

\section{Valsad district}

In case of Valsad the SPI trend of north east monsoon season observed decreasing trends. Analysis also revealed that there is a lower value of Kendall's tau (-0.084), S- Statistics (25.000) and Sen's Slope (-0.001) (Table 5).

\section{Winter season}

Standard precipitation index of winter season at south Gujarat from years 1991-2015 are presented in table 5. The significant decreasing trend was noticed at the entire district because of lower value of Kendall's tau, S- Statistics and Sen's Slope.

\section{Dang district}

The data analysis of Dang district from table 5 showed that during winter season showed decreasing trend with Kendall's tau value 0.189 and S- Statistics -16.000 with the Sen's Slope value of 0.000 .

\section{Navsari district}

At Navsari district the winter season, analysis of SPI trends showed the decreasing trends in case of year 1991-2015 with the lower value of Kendall's tau of -0.188, S- Statistics of 47.000 and Sen's Slope of 0.000 (Table 5).

\section{Valsad district}

In case of Valsad the SPI trend of winter season observed decreasing trends. Analysis also revealed that there is a lower value of Kendall's tau (-0.407), S- Statistics (104.000) and Sen's Slope (-0.006) (Table 5).

\section{Annual}

Standard precipitation index of annual rainfall at south Gujarat from years 1991-2015 are presented in table 5. The significant increasing trend was noticed at the entire district except Valsad district.

\section{Dang district}

The data analysis of Dang district from table 5 showed that during annual season showed increasing trend with Kendall's tau value 0.007 and S- Statistics 2.000 with the Sen's Slope value of 0.001 .

\section{Navsari district}

The data analysis of Dang district from table 5 showed that during annual season showed increasing trend with Kendall's tau value 0.127 and S- Statistics 38.000 with the Sen's Slope value of 0.023 .

\section{Valsad district}

In case of Valsad the SPI trend of annual season observed decreasing trends. Analysis also revealed that there is a lower value of Kendall's tau (-0.033), S- Statistics (-10.000) and Sen's Slope (-0.006) (Table 5).

Analysis of the Mann-Kendall trend and Sen's slope was done in different four era of thirty years (e.g. 1901-30, 1931-60, 1961-90 
and 1991-2015) on the basis of past 115 years (1901-2015) rainfall data of three districts of south Gujarat (Dang. Navsari and Valsad). Results showed that annual standard precipitation index at Dang shows the increasing trend in all the era while, that of Navsari and Valsad districts are declining trends in two era (1901-30 and 1931-60) and increasing in two era (1961-90 and 19912015). The pre monsoon season standard precipitation index of Dang district shows decreasing trends in all era whenever, Navsari and Valsad districts was recorded decreasing trends in two era (1901-30 and 1961-90) and increasing trends in remaining two era (193160 and 1991-2015). In case of south west monsoon Dang and Valsad district showed most frequently increasing trends in almost all of the era same as Navsari district showed the decreasing trends in standard precipitation index in most of the era. The Navsari district showed increasing trends in most of the era while, Dang and Valsad districts showed declining trends in standard precipitation index in most of the era in case of north-east monsoon. Analysis of standard precipitation index of winter season revealed that all the districts showed the decreasing trends in all the era except one era (1901-30).

\section{Acknowledgement}

The authors are thankful to India Meteorological Department, Pune for facilitating this work. Authors are also grateful to anonymous reviewer for his valuable comments to improve the quality of research paper.

\section{References}

Alley, R. B., and Coauthors. (2007), Summary for policymakers. Climate Change 2007: The Physical Science Basis, S. Solomon et al., Eds., Cambridge University Press, 1-18.
Bagla P. 2006. Controversial rivers project aims to turn India's fierce monsoon into a friend. Science 313(5790):1036-1037.

Chang JH. 1967. The Indian Summer Monsoon. Geographical Review 57(3): 373-396.

Edwards D. C. and McKee, T. B., (1997). Characteristics of $20^{\text {th }}$ century drought in the United States at multiple scales. Climatology Report 97-2, Department of Atmospheric Science, Colarado state University, Fort Collins.

Gilbert, R. O., (1987). Statistical methods for environmental pollution monitoring. Van No strand Rienhold Company, Inc., New York.

Gupta, A., Khan, S. A. and Saha, A. (2010). Characterization of agricultural climate for crop planning under rainfed condition in laterite region of West Bengal. In: "Agrometeorological Services for Farmers". (Ed.Vyas Pandey). pp. 90-97. (Anand Agricultural University, Anand)

Helsel, D. R. and Hirsch, R. M., 2002, "Statistical methods in water resources", U. S. Geological survey technique of water resources investigations, book 4, chapter A3, 524.

Jain, S. K., Keshri, R., Goswami, Sarkar and Chaudhry, A., 2009, "Identification of drought-vulnerable areas using NOAA AVHRR data", Int. J. Rem. Sens., 30, 10, 2653-2668.

Kendall, M. G., (1975). Rank correlation methods. $4^{\text {th }}$ edition, Charles Griffin, London.

Kulkarni A, and Kriplani R H. 1998. Rainfall patterns over India; Classification with Fuzzy c Means Method. Theoretical and Applied Climatology 59(3):137-146.

McBean, E. and Motiee, H., (2008). Assessment of impact of climate change on water resources. A long term analysis of the Great Lakes of North America. Hydro/. Earth Syst. Sci., 12: 
239-255.

McKee, T. B., Doesken, N. J. and Kleist, J., (1993). The relationship of drought frequency and duration to time scales. In: Proceedings of the $8^{\text {th }}$ conference on Applied Climatology, American Meteorology Society, Boston, 179-184.

Mishra, A. K. and Singh, V. P. 2010. A Review of Drought Concepts. J. Hydrol., 391:202-2-16.

Paulo, A. A., Rosa, R. D. and Pereira, L. S., (2012). Climate trends and behaviour of drought indices based on precipitation and evapotranspiration in Portugal Nat. Hazards Earth Syst. Sci., 12: 14811491.

Ramana Rao, B. V., Biradar, B. R., Surpur, S. S. and Rao, M. G. (1979). A climatological study on water availability to crops in different types of soils in Gulbarga region. J. Indian Sc. Soil Sci., 27: 441-446.

Sattar, A., Kumar, M., Bobade, P. and Chandrawanshi, S., 2013. Assessing the length of growing season and drought incidence in Bihar. Journal of Agrometeorology 15 (Special Issue-I): 1-3.

Sen, P. K., (1968). Estimates of the regression coefficient based on Kendall's. J. Am. Stat. Assoc., 63: 1379- 1389.

Thiel, H., (1950). A rank-invariant method of linear and polynomial regression analysis. Part 3, Proceedings of Koninalijke Nederlandse Akademie van Weinenschatpen A. 53: 1397-1412.

Viessman, W., Krapp, J. W. and Harbough, T. E., (1989). Introduction to Hydrology. Third edition, Harper and Row Publishers lnc, New York.

Wilhite, D. A. and Glantz, M. H., 1985, "Understanding the drought phenomenon: The role of definitions", Water Int., 10, 111-120.

WMO, (2012). Standardized Precipitation Index-User Guide. World Meteorological Organization, WMO NO, 1090, 16.

\section{How to cite this article:}

Neeraj Kumar, S.K. Chandrawanshi, C.C. Panchal and Radadia, G.G. 2017. Characterization and Monitoring of Drought during Pre and Post Industrialization Era of summer and Winter Monsoon by Using Non Parametric Test at South Gujarat, India. Int.J.Curr.Microbiol.App.Sci. 6(12): 3785-3801. doi: https://doi.org/10.20546/ijcmas.2017.612.436 